\title{
DOI https://doi.org/10.30525/978-9934-26-044-5-16
}

\section{ОСОБЛИВОСТІ РУХОВОЇ АКТИВНОСТІ СТУДЕНТІВ ЗАКЛАДУ ВИЩОЇ ОСВІТИ}

\author{
Кошелева О. О. \\ кандидат наук з фізичного виховання і спорту, \\ дочент кафедри теорії і методики фізичного виховання \\ Придніпровська державна академія фізичної культури і спорту \\ Сидорчук Т. В. \\ кандидат наук з фізичного виховання і спорту, \\ дочент кафедри теорії і методики фізичного виховання \\ Придніпровська державна академія фізичної культури і спорту \\ Анастасьсва 3. В. \\ старший викладач кафедри теорії і методики фізичного виховання \\ Придніпровська державна академія фізичної культури і спорту \\ м. Дніпро, Украӥна
}

Вступ. На тлі інтенсифікації навчального процесу у закладах вищої освіти за останні роки в Україні відзначається неухильна тенденція зниження об'єму рухової активності студентів, що негативно позначається на їх фізичному розвитку, фізичній підготовці i функціональному стані $[6,8]$.

Дійсні умови життя диктують високі вимоги до біологічного, особистісного та професійного розвитку майбутніх фахівців, конкурентоспроможних на ринку праці. Формування самостійної особистості, яка $\epsilon$ інтелектуально й фізично розвиненою, володіє високим рівнем професійних знань, умінь, навичок та творчих здібностей $є$ одним з ключових завдань сучасної системи вищої освіти $[4,5]$. Поряд із тим, його реалізація неможлива без спрямованого підвищення фізичної й розумової роботоздатності, зміцнення здоров'я студентів за допомогою раціонально організованої рухової активності в умовах навчання у закладі вищої освіти $[1,3,9]$.

Мета - визначити рівень рухової активності студентів закладу вищої освіти для обгрунтування шляхів його підвищення.

Результати. Дослідження проведені у Дніпровському національному університеті імені Олеся Гончара. У констатувальному експерименті взяли участь 68 студентів $17-18$ років, з яких 37 юнаків та 31 дівчина.

Визначення рівня рухової активності студентів проводилося за допомогою методики хронометражу. Реєструвалася кожна діяльність, яка займає більше 5 хвилин часу. Описується день в цілому з моменту, 
коли студент прокинувся після нічного сну, до того часу, коли він пішов спати.

Уся рухова активність людини розподіляється на п'ять рівнів: базовий, сидячий, малий, середній та високий. Для кожного рівня $\epsilon$ відповідні види фізичної активності:

- до базового рівня належать сон, відпочинок лежачи;

- до сидячого - поїздка в транспорті, читання, малювання, перегляд телепередач, настільні та комп’ютерні ігри, харчування;

- до малого - особиста гігієна, заняття в ЗВО (крім фізичного виховання), ходіння пішки;

- до середнього - домашня робота по господарству, прогулянки, ранкова гімнастика;

- до високого - фізичні вправи під час спеціально організованих занять, інтенсивні ігри, біг, катання на санках, ковзанах, велосипеді тощо [7].

Нами визначено кількість часу та енерговитрати на різні рівні рухової активності.

Юнаки витрачають на базовий рівень 7 годин 15 хв., на сидячий 8 годин 10 хв., на малий -4 год. 55 хв., на середній -3 години, на високий - 40 хв. Загальні витрати енергії протягом доби у юнаків складають 2624,5 ккал, що є нижчим за норму для даної вікової групи.

Дівчата витрачають на базовий рівень 7 годин 55 хв., на сидячий 8 годин 25 хв., на малий -3 години 30 хв., на середній -3 години 35 хв., на високий - 35 хв. Загальні енерговитрати дівчат склали 2595 ккал, що є вищим за норму для даного віку. При цьому слід відмітити малу кількість часу, яку юнаки та дівчата витрачають на високий рівень рухової активності.

Слід зазначити, що норма рухової активності для студентів складає 8-10 год. на тиждень [2], що відповідає високому рівню, тобто більшість студентів не задовольняють біологічну потребу у рухах.

Висновки. Результати дослідження показали недостатньо високий рівень рухової активності студентів. Юнаки і дівчата недостатньо часу приділяють спеціально організованим формам занять фізичними вправами. Враховуючи тенденцію скорочення часу, відведеного на заняття 3 дисципліни «Фізичне виховання» в закладі вищої освіти, необхідно використовувати позанавчальні форми організації процесу фізичного виховання у вищій школі. Одним із основних моментів, якому слід приділити увагу - це врахування мотивації студентів до фізкультурно-оздоровчої діяльності, підбір засобів фізичного виховання, які викликають стійкий інтерес у тих, хто займається.

\section{Література:}

1. Азаренков В. М. Шляхи формування мотивації до занять фізичною культурою у студентів факультету мистецтв. Актуальні 
проблеми фізичного виховання різних верств населення: II Всеукраїнська науково-практична конференція, Харків, 2016. С. 12 - 17.

2. Грибан Г.П. Життєдіяльність та рухова активність студентів. Житомир : Рута, 2009. 205 с.

3. Загальні поняття і детермінанти рухової активності студентської молоді / Грибан Г.П., Яблонська А.М., Пантус О.О., Ободзінська О.В., Сметанникова Т.В., Пилипчук П.Б. Zprïtvy vëdecké ideje - 2013. Tëlovychova a sport. 2013. C. $78-81$.

4. Кошелева О.О. Оптимізація організаційно-методичних умов системи фізичного виховання у закладах вищої освіти: дис. ... канд.наук з фіз.вих. і спорту: 24.00.02 / Придніпровська державна академія фізичної культури і спорту. Дніпро, 2019. 294 с.

5. Кремень В.Г. Проблеми якості української освіти в контексті сучасних цивілізаційних змін. Український педагогічний журнал. 2015. № 1. C. $8-15$.

6. Круцевич Т., Малахова Ж. Проблеми реформувань у системі фізичного виховання закладів вищої освіти. Спортивний вісник Придніпров’я. 2020. № 1. С. 268 - 277.

7. Круцевич Т.Ю., Воробйов В.І., Безверхня Г.В. Контроль у фізичному вихованні дітей, підлітків і молоді: навч. посіб. К. Олімпійська література, 2011.246 с.

8. Марченко О. Формування фізичної культури студентів у процесі навчання у вищих навчальних закладах. Теорія і практика фізичного виховання і спорту. 2008. № 2. С. $83-84$.

9. Перекопський С., Порохненко О. Вплив рухової активності на емоційний стан студентів. Педагогічні науки: теорія, історія, інноваційні технології. 2016. № 3 (57). С. 246 - 253. 